\title{
Magdalena Cuprjak
}

Uniwersytet Mikołaja Kopernika w Toruniu

\section{Paradygmaty w perspektywie zmian społecznych. Zarys problemu \\ Paradigms in the Perspective of Social Changes. Outline of the Problem}

Streszczenie. Artykuł podejmuje próbę zarysowania tendencji we współczesnych badaniach społecznych, ze szczególnym uwzględnieniem badań pedagogicznych. Podstawą rozważań są paradygmaty, jako podstawa tworzenia wiedzy, które rozpatruję z trzech perspektyw: stabilizacji, zmiany oraz użyteczności. Posługuję się przykładem osobistych zmagań nad dylematem związanym z adekwatnością badań prowadzonych w paradygmacie pozytywistycznym, ale w sytuacji zwrotu humanistycznego i postmodernistycznego. Jednym z rozwiązań powstałego dylematu jest odwołanie się do celu badań i użyteczności przyjętej perspektywy w stosunku do ontologii i epistemologii zjawiska.

Słowa kluczowe: paradygmat; stabilizacja paradygmatów; użyteczność paradygmatów; zwrot w badaniach społecznych.

Summary. The article is an attempt to present trends in contemporary social researches, with particular focus on educational research. The basis for discussion are paradigms that are examined from three perspectives: stabilization, change and utility. I make use of example of a personal struggle with the dilemma of associated with adequacy of research in the positivist paradigm, but in case of humanistic and postmodern return. One solution to this dilemma is to appeal to purpose of researches and utility of adopted perspective in relation to ontology and epistemology phenomenon.

Keywords: paradigm; stabilization of paradigms; utility of paradigm; return of social researches. 


\section{Wprowadzenie}

Określoną dziedzinę wiedzy można nazywać nauką wtedy, gdy posiada naukową metodologię (Frnakfort-Nachmias, Nachmias, 2001, s. 18). Naukowa metodologia natomiast, to zespół praktyk badawczych, składających się na proces badania naukowego, ,regulowanego przez normy stworzone przez społeczność naukowców" (Rubacha, 2008, s. 9). W powyższą definicje wpisane są dwa bardzo istotne i zależne wobec siebie elementy - normy oraz naukowcy. Normy, składające się na określony paradygmat naukowy, to czynniki formalne, które z jednej strony ustalane są przez grupy ludzi, a drugiej regulują ich pracę naukową. Skoro więc są tworzone przez ludzi i dla ludzi, to chciałabym zastanowić się nad ich względną trwałością i stabilnością. Z jednej bowiem strony statyczność norm daje poczucie bezpieczeństwa, a tym samym pozwala na sprawne poruszanie w badanej przestrzeni. Z drugiej strony sztywne i bezrefleksyjne ich stosowanie może ograniczać zauważenie wielu subtelnych zjawisk, które można by dostrzec, poszerzając, a nawet zmieniając optykę obserwacji.

Według Thomasa Kuhna, uznawanego za klasyka w zakresie filozofii nauki (1968; Sławecki, 2012, s. 58), w historii rozwoju nauki można wyodrębnić dwa główne procesy: dominacji „normalnej” nauki instytucjonalnej, kiedy mamy do czynienia ze stabilizacją pewnego zestawu przekonań, składających się na określony paradygmat oraz rewolucji naukowej, prowadzącej do zerwania części naukowców z podzielanymi dotąd przekonaniami (Kuhn 1968, s. 35). Biorąc pod uwagę rozważania Kuhna na temat funkcjonowania wiedzy i budowania nauki, na paradygmaty naukowe można patrzeć z co najmniej dwóch perspektyw - stabilizacji oraz zmiany, na które, według mnie, można nałożyć trzecią, jaką jest utylitaryzm, ściśle związany z celem badań i strukturą badanego zjawiska (rys. 1).

Odwołując się do przedstawionego schematu i skupiając swoją uwagę na badaniach społecznych, chciałabym zastanowić się nad konsekwencjami dla ich praktykowania, wynikającymi z dokonujących się zmian społecznych. Zgodnie bowiem z logiką rozwoju normy powinny ulegać zmianie i ewolucji wraz z rozwojem rzeczywistości, leżącej u podstaw zainteresowania danej dziedziny. W związku z tym chciałabym przedstawić kierunek obserwowanych zmian. Czy mają one charakter rewolucyjny, czy raczej ewolucyjny? Czy dzieją się w ramach podstawowych paradygmatów, czy zmierzają w stronę ich przekroczenia i budowy nowych? Poruszę również kwestię utylitaryzmu paradygmatów i spróbuję odpowiedzieć na pytanie, czy w postmodernistycznej rzeczywistości, czyli sytuacji permanentnej zmiany, użyteczność 
nadal jest platformą dla paradygmatycznego dialogu. W przykładach będę odwoływać się do badanej przeze mnie kategorii tożsamości.

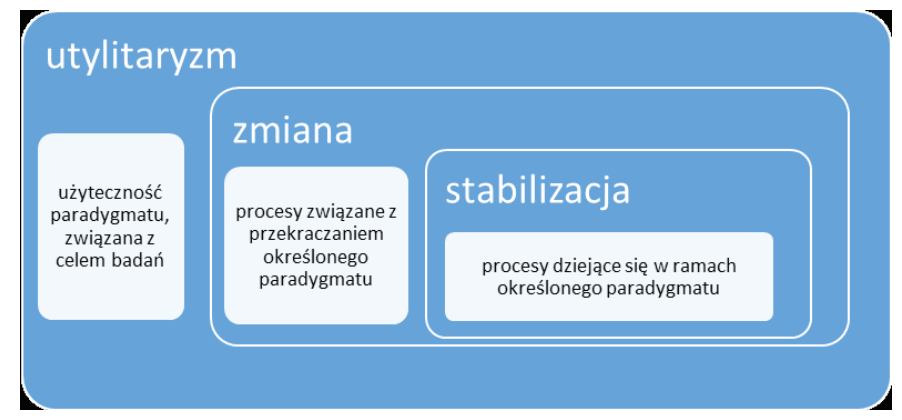

Rys. 1. Układ zmian perspektywy badawczej

Żródło: opracowanie własne.

\section{Paradygmaty - perspektywa stabilizacji}

Wskazaną wcześniej perspektywę stabilizacji i zmiany można przedstawić w kontekście historycznym. Teorie naukowe mają bowiem swój czas w określonej epoce i funkcjonują dopóty, dopóki nie zostaną zweryfikowane - udoskonalone, rozszerzone lub całkowicie wyparte przez inne teorie lub dopóki są w danym czasie użyteczne. Dzieje się tak zarówno dzięki permanentnej pracy nad udoskonalaniem metod i narzędzi badawczych w ramach określonej perspektywy - danego paradygmatu, jak i dzięki zmianom perspektywy w ogóle. Określony paradygmat jest użyteczny, jeżeli w jego ramach możliwe jest sprawne poruszanie się w badanej problematyce. Można rozwijać i udoskonalać procedury badawcze do momentu, kiedy poziom wyjaśnienia istoty zjawiska odpowiada założeniom ontologicznym i epistemologicznym. Jednakże w sytuacji, gdy zjawisko „wymyka” się poza zarysowane ramy, czyli ontologicznie nie mieści się w istniejącym paradygmacie (paradygmatach), następują zmiany, nazywane przez Kuhna (1968, s. 68) „anomaliami”, które mogą prowadzić do rewolucji naukowej. Rewolucja polega na przełamaniu określnej struktury paradygmatycznej i sformułowanie nowego zestawu zasad.

Prowadzenie badań naukowych z perspektywy stabilizacji oznacza przyswojenie określonych reguł postępowania, uznanie ich za słuszne i konsekwentne działanie wewnątrz wyznaczonych przez nie ram. Według Kuh- 
na zaliczenie siebie do jednej z grup naukowych (rozumiane jako „wyznawanie" jednego z paradygmatów) pozwala na zawodowe uprawianie nauki (op. cit., s. 36). W sytuacji gdy badacze przyjmują za oczywisty pewien zbiór założeń epistemologicznych, nie muszą na nowo budować swojej dziedziny i nieustannie uzasadniać każdego $\mathrm{z}$ wprowadzonych pojęć, zostały one bowiem już zdefiniowane w podręcznikach (ibidem). Można zauważyć więc dużą ostrożność Kuhna wobec pojawiających się „,anomalii”, leżących u podstaw zmiany teorii naukowych oraz paradygmatów. Zaleca raczej trzymanie się określonych reguł, ewentualnie ich rozbudowę, czyli rozwój wewnętrzny. Chciałabym tu podkreślić, że stabilizacja to nie stagnacja i w ramach paradygmatów dzieje się wiele procesów rozwojowych.

Trzymanie się wypracowanych procedur można polecać szczególnie młodym adeptom nauki. Przywołując myśl Dariusza Kubinowskiego, wyrażoną podczas Seminarium Metodologii Pedagogiki w Gdańsku w 2010 roku, można powiedzieć, że najpierw należy nauczyć się pracy w ramach paradygmatów, aby można było je przekroczyć. Pomijanie ich bowiem na samym początku drogi naukowej może (a więc nie musi) powodować chaos i trudność w obronie dokonywanych interpretacji. Jednak istnieje ryzyko zamknięcia się wewnątrz jednej perspektywy i brak zrozumienia wobec pozostałych.

Biorąc pod uwagę proces rozwoju nauki, odbywający się $w$ ramach określonego paradygmatu, znów można posłużyć się ustaleniami Kuhna, który uważa, że „nauka instytucjonalna [...] ma charakter zdecydowanie kumulatywny, jest niezwykle skuteczna w swym dążeniu do stałego poszerzania zakresu i zwiększania precyzji wiedzy naukowej" (Kuhn 1968, s. 68). Naukę można zatem opisać jako stabilny monument zbudowany z mniejszych, pasujących do siebie elementów, który prawdopodobnie umacnia poczucie pewności, co do zgromadzonej wiedzy. Taki kierunek refleksji, obecny jest w założeniach pozytywizmu i postpozytywizmu, opisywanych w sarkastyczny sposób przez Egona Gubę i Yvonnę Lincoln. Głoszą oni, że akumulacja wiedzy, to sukcesywna budowa "gmachu wiedzy”, składającego się z poszczególnych „klocków” o charakterze generalizacji oraz połączeń przyczynowo-skutkowych (Guba, Lincoln 2009, s. 286). Taki związek można interpretować $z$ dwóch perspektyw - historycznej oraz dziedziny naukowej. Rozważania Kuhna na temat nauki opierają się głównie na doświadczeniach nauk fizycznych i przyrodniczych, w których doświadczenie zjawiska jest warunkiem poznania. Ponadto intensywna działalność naukowa Kuhna przypada na okres lat 60., w których dominowała idea Augusta Comte’a: budowa nowego zharmonizowanego społeczeństwa na podstawie sprawdzo- 
nych badań naukowych o charakterze obiektywnych obserwacji i eksperymentów (Sławecki 2012, s. 62).

Współcześnie w praktyce badań edukacyjnych funkcjonują dwie główne klasyfikacje paradygmatów, które zostały już wielokrotnie opisane w podręcznikach do metodologii: klasyfikacja opracowana przez Gibsona Burrella i Garetha Morgana (m in. Rubacha 2008, s. 313; Sławecki 2012, s. 75) oraz klasyfikacja Egona G. Guby i Yvonny S. Lincoln (2009, s. 281).

Pierwsza klasyfikacja składa się z dwóch wymiarów. Pierwszy wymiar jest wypadkową obiektywnej i subiektywnej epistemologii badanych zjawisk. Epistemologia obiektywna związana jest $\mathrm{z}$ ontologią realizmu i determinizmu, które głoszą, że badana rzeczywistość jest niezależna od „ludzkiego umysłu" (Nowaczyk 2008, s. 113), a wpisane w nią działania mają charakter obiektywny, przewidywalny i trwały (Rubacha 2008, s. 163). W epistemologię subiektywną wpisane są natomiast nominalizm i woluntaryzm, według których rzeczywistość nie istnieje realnie i niezależnie od ludzkiego umysłu, ponieważ nie istnieją rzeczy, ale postrzegane w różny sposób pojęcia, natomiast ludzkie działania są indywidualne i nieprzewidywalne (Rubacha 2008). Drugi wymiar jest wypadkową definicji natury społeczeństwa - regulacji i radykalnej zmiany. Socjologia regulacji skupia się na badaniach społeczeństw z punktu widzenia ich jedności i spójności (Sławecki 2012, s. 76). Badania w tym kontekście zmierzają do opisu procesów związanych z trwaniem określonych społeczeństw. Natomiast socjologia radyklanej zmiany zakłada, że „człowiek dąży do oswobodzenia się ze struktur, które ograniczają jego potencjał rozwojowy" (Sławecki 2012). Badania w tym kontekście zmierzają do opisu różnic i podziałów społecznych, utrudniających m in. emancypację jednostki.

Dzięki opisanym wymiarom powstała przestrzeń dla czterech podstawowych paradygmatów: radykalnego humanizmu i interpretatywizmu, związanych z wymiarem subiektywnym, oraz radyklanego strukturalizmu i funkcjonalizmu, związanych z wymiarem obiektywnym. Można dodać, że im bliżej ontologii subiektywnej, tym mniej metodologii opartej na metodach statystycznych.

Druga klasyfikacja, Guby i Lincoln (2009) opiera się wprost na założeniach ontologicznych, epistemologicznych i metodologicznych. W zakresie założeń ontologicznych akcentuje się realizm i relatywizm, natomiast w zakresie założeń epistemologicznych obiektywizm i subiektywizm. Na tej podstawie wyróżniono pięć paradygmatów naukowych: pozytywizm, postpozytywizm, teoria krytyczna, konstruktywizm oraz uczestnictwo (Guba, Lincoln 2009, s. 285). Ostatni paradygmat (do którego powrócę w dalszej 
części tekstu) jest stosunkowo nowy, powstał w efekcie zaistniałych w ostatnim czasie „anomalii”, niemieszczących się w już istniejących i niedających możliwości poszerzenia, ramach.

Mając do dyspozycji opisane wyżej klasyfikacje paradygmatów, można mieć nadzieję, że każda badaczka czy badacz „znajdzie coś dla siebie”. Jeżeli bowiem, zjawisko leżące w polu mojego zainteresowania, np. tożsamość jednostki, jest widziana przeze mnie jako niezależny od mojego poznania byt realny i zakładam, że jestem w stanie dokonać obiektywnej, zewnętrznej obserwacji, wtedy wybieram paradygmat pozytywistyczny (względnie postpozytywistyczny) i związane z nim strategie badań ilościowych o cechach wyjaśnień nomotetycznych. Na podstawie teorii buduję adekwatny konstrukt teoretyczny, a następnie tworzę wystandaryzowane narzędzie w postaci np. testu do badania tożsamości, w którym wszystkie badane osoby traktuję jednakowo i jako pewnego rodzaju „nośniki informacji” o własnej tożsamości (np. Cuprjak 2007). Natomiast w sytuacji, gdy interesujące mnie zjawisko tożsamości traktuję w kategoriach relatywnych pojęć, wprost nieuchwytnych i wymykających się spod wszelkich uogólnień, wybieram paradygmat konstruktywistyczny i związane $\mathrm{z}$ nim strategie jakościowe o cechach wyjaśnień idiograficznych (np. Cuprjak 2016).

Sytuacja wydaje się oczywista, jednakże można próbować wyobrazić sobie, że pojawiające się w historii rozwoju nauki „anomalie”, nie pasujące do obowiązującego repertuaru norm są ignorowane lub odrzucane jako nienaukowe. Taka (na szczęście niewiarygodna) stagnacja uniemożliwiłaby rozwój perspektyw badawczych, a wspomniane przeze mnie badania nad tożsamością utkwiłyby w jednowymiarowym i nieadekwatnym wobec rozwoju społecznego punkcie. Sposób widzenia kategorii tożsamości, podobnie jak wielu innych kategorii społecznych na przestrzeni ostatnich kilkudziesięciu lat, które krótko można scharakteryzować jako przejście od tożsamości romantycznej poprzez modernistyczną do postmodernistycznej, uległ ewolucyjnym przekształceniom. Z kategorii definiowanej jako esencja, dająca się dość łatwo klasyfikować, zmieniła się w kategorię zmienną, płynną i procesualną (np. Melosik 2014). W tym kontekście można powiedzieć, że rozwój wiedzy w określonym zakresie jest możliwy dzięki zmianom dominujących paradygmatów. W naukach przyrodniczych rozwój ten polega na weryfikacji negatywnej, czyli z chwilą pojawienia się nowego paradygmatu, poprzednie uznawane są za fałszywe. Badacze trzymający się dawnego, zdezaktualizowanego poglądu zmuszeni są pracować w izolacji, na marginesie nauki, a nawet związać się z uprawianiem innej dziedziny (Kuhn 1968, s. 35). 
W naukach społecznych, w toku rozwoju, nowe paradygmaty zyskują natomiast nowych zwolenników, a stare tracą swoją popularność, ale nie są w całości odrzucane jako fałszywe. Tożsamość badana jest obecnie zarówno w kategoriach obiektywnych, jak i subiektywnych, ponieważ nadal funkcjonują zróżnicowane teorie, które te rodzaje epistemologii potwierdzają. Każdy z paradygmatów oferuje bowiem „odmienny sposób patrzenia na życie społeczne człowieka; każdy czyni pewne założenia co do natury rzeczywistości społecznej” i każdy „uwzględnia pewne aspekty społecznego życia nieobecne w pozostałych, w jednocześnie pomija wątki ujawniane gdzie indziej" (Babbie 2004, s. 57). Współistnienie paradygmatów społecznych odbywa się raczej w atmosferze dialogu, aczkolwiek pojawiają się momenty, w których dyskusja o dominacji jednych nad drugimi staje się bardziej ożywiona.

Podczas spotkań na seminariach i sympozjach metodologicznych można co jakiś czas usłyszeć głosy, szczególnie w grupie badaczek i badaczy praktykujących badania w strategii jakościowej, że to właśnie oni „robią” dobre badania, ponieważ tylko te badania zmierzają w kierunku zrozumienia zjawiska, a nie „zimnego” opisu statystycznego. Dysonans zaostrza się zwykle wtedy, gdy po obu stronach stają osoby prowadzące tylko i wyłącznie badania w zakresie paradygmatów wyznaczających przestrzeń dla strategii o charakterze jakościowym lub tylko ilościowym. Na szczęście większość opinii to głosy rozsądku, według których perspektywy badań edukacyjnych są na tyle pojemne, że pomieszczą wszystkie, rzetelne i wiarygodne badania. Parafrazując słowa profesor Anny Izabeli Brzezińskiej, wyrażone podczas Warsztatów Metodologii Jakościowych w Bydgoszczy (2013 r.), można powiedzieć, że nie ważne, jakie badania robimy, ważne, aby robić je dobrze.

\section{Paradygmaty - perspektywa zmiany}

Z rozwojowego punktu widzenia paradygmaty w naukach społecznych ulegały stopniowym przemianom. Wiek XIX to prymat pozytywizmu, a w naukach pedagogicznych - pedagogiki pozytywistycznej i tworzenie wiedzy pewnej, opartej na empirycznym pomiarze „faktów” (Hejnicka-Bezwińska 2004, s. 197). Głównym założeniem pozytywizmu, odnoszącym się do wiedzy naukowej, jest możliwość wyrażania jej „w terminach odnoszących się bezpośrednio do pewnej rzeczywistości, ewentualnie do takich aspektów, które są uchwytne za pomocą zmysłów" (Giddens 2009, s. 105). W związku z tym, w badaniach społecznych można stosować taką samą metodologię, jak w przypadku badań fizycznych (ibidem). Dzięki takiemu pojmowaniu 
wiedzy, a zatem i naukowej prawdy, uzasadnione było twierdzenie o wytwarzaniu „wiedzy pozytywnej” w formie pedagogicznych doktryn (Hejnicka-Bezwińska 2010, s. 42).

Paradygmat pozytywistyczny był użyteczny wtedy, gdy dyscypliny społeczne zaczynały budować swoją naukową tożsamość, zgodnie z ideą oświeceniowego „szkiełka i oka”. Za naukowe uznawane były w tym czasie wyłącznie obiektywne, precyzyjnie zmierzone i policzalne fakty, co przypisuje się raczej naukom przyrodniczym, a nie humanistycznym. Kluczowe dla założeń pozytywizmu było traktowanie człowieka nie w kategoriach indywidualnej, niezależnej jednostki, ale pewnej abstrakcji w realnym i rzeczywistym świecie społecznym (Hejnicka-Bezwińska 2004, s. 199). Mówiąc metaforycznie - człowiek to jeden z drobnych elementów, wchodzących w skład sprawnie (lub nie) pracującej maszyny o nazwie „społeczeństwo”.

Wraz z rozwojem myśli naukowej, przechodzącej w fazy rewolucji, przełamywane były kolejne paradygmaty, które w praktyce badawczej pełniły funkcję ograniczającą pole poznania. W odpowiedzi na zmiany społeczne, np. procesy emancypacyjne, powstawały kolejne, w coraz większym stopniu akcentujące podmiotowość oraz unikatowość każdej z badanych osób. Zgodnie z zasadą rozwoju można zakładać, że obecnie funkcjonująca klasyfikacja nie jest ostateczna, aczkolwiek aktualne zmiany odbywają się raczej wewnątrz paradygmatów i na ich pograniczach. Osobiście, prowadząc badania nad tożsamością, przeszłam drogę ewolucji, przechodzącej czasami w stan rewolucji. Pierwsze kroki badawcze stawiałam, stosując strategię ilościową (wspomniany wcześniej test do badania tożsamości). Wykonałam swoją pracę najlepiej, jak umiałam, dokonałam wyjaśnień w ramach zastosowanych teorii (głównie psychologicznych) i zweryfikowałam zbudowany konstrukt. W miarę upływu czasu i docierania do nowej literatury (głównie socjologicznej), dotychczasowe definicje tożsamości zaczęły ulegać przekształceniom, kierując się w stronę ontologii nominalizmu. To przejście spowodowało we mnie wewnętrzny sprzeciw wobec wykonanych wcześniej badań. Nieustannie nurtowało mnie pytanie: „co ja wiem o ludziach badanych przeze mnie za pomocą testu?” Niestety odpowiedź brzmiała: „niewiele”.

Mój osobisty bunt spowodowany był poszerzeniem perspektywy definiowania interesującego mnie zjawiska, związanym z procesami postmodernistycznymi. Guba i Lincoln (2009, s. 281) współcześnie zwracają uwagę na wyraźny zwrot w naukach społecznych „w kierunku bardziej interpretacyjnych, postmodernistycznych i krytycznych praktyk i teoretyzowania”. Trudno nie zauważyć, iż w ponowoczesnej rzeczywistości (m in.: Sztompka 2007; Melosik 2014), czy też nazywanej inaczej - późnej nowoczesności 
(m.in. Giddens 2010; Hejnicka-Bezwińska 2010) lub nowoczesności refleksyjnej (Bauman 2008), nastąpiły zmiany w obszarze sposobów i celów poznania w ogóle. Epistemologiczny charakter zmian, o którym pisze $\mathrm{m}$ in. Teresa Hejnicka-Bezwińska (2010, s. 43), polega głównie na rezygnacji $z$ orientacji pozytywistycznej i zwrócenie uwagi na cechy charakterystyczne dla nauk społecznych, którym bliżej do nauk humanistycznych niż przyrodniczych (Rys. 2).

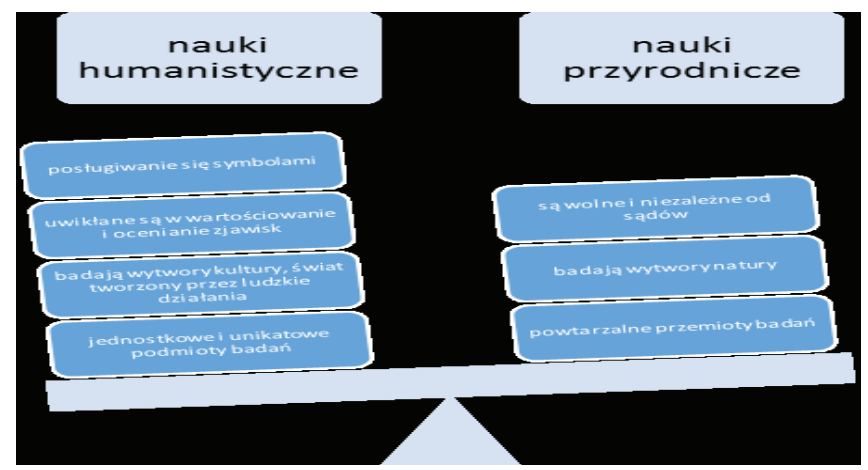

Rys. 2. Różnice pomiędzy naukami humanistycznymi a przyrodniczymi Źródło: Heller 2009, cyt. za: Sławecki 2012., s. 61; Giddens 2009, s. 87.

Do głównych cech nauk humanistycznych należy zaliczyć przede wszystkim podmiot badania, czyli człowieka, który na poziomie jednostkowym jest bytem indywidualnym, a na poziomie społeczeństwa różnorodnym. Unikatowy człowiek tworzy unikatową kulturę i posługuje się unikatowymi symbolami, a ponadto uwikłany jest w sieć wartości, postaw i sądów. W takiej sytuacji, w której dominuje dbałość o dobro każdego człowieka, niemożliwe wydaje się prowadzenie badań według zasad epistemologii obiektywnej. Jest to więc wyraźny zwrot humanistyczny (por. $\mathrm{m}$ in. Giddens 2009; Kubinowski, 2011), w którym każdy człowiek jest wartością, wymagającą humanistycznego, indywidualnego i kontekstualnego rozumienia (Kubinowski 2011, s. 119).

Zatem nauki społeczne, a w tym również pedagogika, ulegają procesom rozwoju, związanym ze zmianami o charakterze globalizacyjnym, ale również wynikającym z konstruowania się ich tożsamości jako nauki, dotyczącym m.in. rozumienia wiedzy. Teresa Hejnicka-Bezwińska (2010, s. 42), mówiąc o zmianie epistemologicznej w pedagogice, związanej z póź- 
ną nowoczesnością, definiuje ją za Kmitą jako przejście od wiedzy rozumianej jako wiedza absolutna w kierunku wiedzy prawdopodobnej i zasadnej w określonych warunkach (Kmita 1987, cyt. za: Hejnicka-Bezwińska 2010, s. 43). Zasadność wiedzy wiąże się z jej użytecznością, ale nie w skali populacji generalnej, tylko raczej lokalnej i skontekstualizowanej. Ponadto bardzo istotną cechą w praktykowaniu edukacji, która dzięki badaniom na ten temat zaczęła być dostrzegana (a może raczej przestała być ignorowana), jest to, że edukatorki i edukatorzy opierają swoje działania nie na wiedzy wyprowadzonej z teorii stricte naukowych, ale głównie na wiedzy potocznej (Hejnicka-Bezwińska 2010, s. 44) czy też na indywidualnych teoriach lub „teoriach specyficznego przypadku” (Elsner 2000, s. 16). Teorie te składają się z uogólnień, dotyczących własnej działalności zawodowej, definicji i interpretacji doświadczanych sytuacji edukacyjnych oraz sądów wartościujących, refleksji i krytycznych ocen własnej wiedzy (Elsner 2000, s. 16; Cuprjak 2010, s. 130).

Zmiana epistemologiczna $\mathrm{w}$ rozumieniu wiedzy nieuchronnie pociąga za sobą zmianę metodologiczną. Chcąc bowiem prowadzić badania zmierzające do zrozumienia zjawisk pedagogicznych lub powstawania teorii indywidualnych, opartych na refleksyjnej praktyce, trzeba wyjść w teren poza własne „laboratorium”, a nawet pozwolić na prowadzenie badań przez praktyków (ewentualnie pod okiem naukowego eksperta).

Obecnie widoczny jest wyraźny rozkwit badań jakościowych. Wzrasta liczba publikowanych podręczników (np. seria Wydawnictwa PWN Metodologia oraz Niezbędnik Badacza), w których dodatkowo widoczne jest duże zróżnicowanie $\mathrm{w}$ obszarze stosowanych metod. Zmiany w badaniach zmierzają w kierunku podmiotowości i egalitaryzmu, a w związku z tym ze zrozumieniem i uczestnictwem. Coraz większy nacisk kładzie się na kontakt $\mathrm{z}$ badanymi osobami na zasadzie prowadzenia badań uczestniczących, a nawet włączanie $\mathrm{w}$ proces badawczy. Prężnie rozwijają się badania w działaniu, oparte na paradygmacie uczestniczącym, w którym nie ma już mowy o badaczach i badanych, ale o współbadaczach, wspólnie wytwarzających wiedzę prowadzącą do zmiany sytuacji problemowej (Czerepaniak-Walczak 2010, s. 324).

Ponadto poza klasycznymi schematami badań jakościowych, tj. etnografią czy studium przypadku, coraz więcej jest badań oraz dyskusji na temat badań autoetnograficznych, w których intuicja i wartościowanie są elementem badań, a nie jego zakłóceniem. Rozwój Internetu, a szczególnie aktywność ludzi na portalach społecznościowych, uruchomił również badania o charakterze etnografii wirtualnej (np. Cichocki, Jędrkiewicz, Zydel 2012) czy netografii (Kozinets 2012). Wiele uwagi poświęca się obecnie 
analizom dyskursu i narracji, których celem jest najpełniejsze zrozumienie współczesnej rzeczywistości. Duże zmiany zaszły również w traktowaniu samego badacza i badaczki, których tożsamość jest istotnym elementem w procesie konceptualizacji badań, gromadzenia danych oraz radzenia sobie w terenie (Rapior 2015, s. 84).

\section{Cele nauk społecznych}

Zarysowane powyżej kierunki zmian w tworzeniu wiedzy nie deprecjonują jednak badań prowadzonych poza mainstreamem. Na paradygmaty można, a nawet powinno się bowiem patrzeć z perspektywy użyteczności naukowej eksploracji, czyli celu badań i struktury badanego zjawiska. Według Earla Babbiego „paradygmaty nie są ani prawdziwe, ani fałszywe; jako sposoby patrzenia są tylko mniej lub bardziej użyteczne". W badaniach nie chodzi bowiem o generowanie nieustannych zmian, ale o rzetelne i wiarygodne zbadanie interesującego badaczy zjawiska.

Krzysztof Rubacha (2008, s. 15) za główny cel badań naukowych uznaje wyjaśnienie. Dzieli je na dwa rodzaje: wyjaśnienie nomotetyczne oraz idiograficzne. Wyjaśnienia nomotetyczne zmierzają w kierunku „wypracowania uniwersalnych praw, twierdzeń odnoszących się do badanej populacji, pozwalając odkrywać prawidłowości rządzące rzeczywistością edukacyjną" (Rubacha 2008, s. 16). Natomiast wyjaśnienia idiograficzne zmierzają do „wypracowania szczegółowych twierdzeń, odnoszących się do badanego terenu i osób" (Rubacha 2008, s. 19). Pierwszy rodzaj wyjaśnień wiąże się ze strategiami jakościowymi, drugi natomiast ilościowymi. Mówiąc inaczej, wyjaśnienia mogą dotyczyć prawidłowości lub kontekstu (Rubacha 2010, s. 56-57).

Chava Frankfort-Nachmias i David Nachmias (2001, s. 23) definiują cel badań w kategoriach dostarczania weryfikowalnej wiedzy. Wiedza pomaga "wyjaśnić, przewidzieć i zrozumieć interesujące nas zjawiska empiryczne" (Frankfort-Nachmias, Nachmias 2001). Zarówno termin „wyjaśnianie”, jak i „przewidywanie” opisuje procedury na poziomie ogólnych generalizacji, przy czym pierwszy dotyczy sytuacji, w której jedno zjawisko może wyjaśniać inne, natomiast drugi termin dotyczy wystąpienia pewnych konsekwencji na skutek pojawienia się określonych warunków wstępnych (Frankfort-Nachmias, Nachmias, s. 25-26). Zrozumienie (verstehen) związane jest natomiast $\mathrm{z}$ empatią i próbą spojrzenia na określoną sytuację z punktu widzenia badanych osób. Według Edmunda Mokrzyckiego (2007, s. 181), rozumie- 
nie jest procedurą specyficznie humanistyczną. Co więcej, „nie jest aktem tajemniczego, bezpośredniego wglądu, nie opiera się na nadprzyrodzonej zdolności penetrowania cudzych doznań. Poznanie przez rozumienie jest poznaniem pośrednim - o stanach ludzkiej świadomości wnioskuje się tu na podstawie ich wypowiedzi, gestów, dzieł itp. obserwowanych własności" (Mokrzycki 2007, s. 182).

Wracając w tym miejscu do przykładu badań o tożsamości, można dojść do wniosku, że oba rodzaje badań są na swój sposób użyteczne, a mój osobisty bunt nie był potrzebny. Badania prowadzone metodą testowania w paradygmacie pozytywistycznym to konstrukt oparty na funkcjonujących teoriach. Dany fragment rzeczywistości został sproblematyzowany do kilku ściśle zdefiniowanych zmiennych, przy rezygnacji z pozostałych. Jak pisze Rubacha, pomimo redukcji rzeczywistości do pewnego ograniczonego modelu mamy kontrolę nad badanym konstruktem, a eliminacja kontekstu sytuacji pozwala na budowę wniosków ogólnych, osadzonych w teoriach (2010, s. 56). Natomiast badania prowadzone metodą etnograficzną, w paradygmacie konstruktywistycznym, zmierzają do zdobywania wiedzy na poziomie jednostkowym, a w efekcie do skonstruowania szczegółowej teorii, osadzonej w określnym kontekście. Każde z badań dostarcza innego rodzaju wiedzy, ponieważ w inny sposób konceptualizuje przedmiot oraz cel badań.

Próbując odpowiedzieć na pytanie o użyteczność paradygmatów, stwierdzam, że pomimo wyraźnych trendów w badaniach pedagogicznych, zmierzających w kierunku humanistycznym, konstruktywistycznym i uczestniczącym, badania pozytywistyczne nadal są ważne i potrzebne. Według Rubachy (2010, s. 62) metodologia odbiła się już od muru zarówno pozytywistycznego, jak i humanistycznego, „już hołdowaliśmy prawidłowościom, i kontekstowi. A to oznacza, że można myśleć o tworzeniu nowej wiedzy, opartej na metodologicznie poprawnej integracji obu porządków".

\section{Film zamiast konkluzji}

W konkluzji chciałabym odnieść się do filmu, w którym w doskonały według mnie sposób przedstawione zostało pewne „pęknięcie” paradygmatu w reakcji na „anomalię”, która pojawiła się w zaprojektowanym badaniu, skazując projekt na pozorne niepowodzenie. Film fabularny Historie kuchenne ${ }^{1}$

1 Historie kuchenne - norwesko-szwedzka komedia obyczajowa z 2003 roku w reżyserii Benta Hamera. „W latach pięćdziesiątych XX wieku szwedzki Instytut Badań Domo- 
poza warstwą obyczajową opisuje też sytuację badawczą, polegającą na prowadzeniu badań w paradygmacie pozytywistycznym. Zewnętrzny obserwator przebywa przez cały dzień w kuchni badanego, siedząc na wysokim krześle/drabince, zapisując kierunki i cele poruszania się mężczyzny po kuchni. Strategia badań została ściśle określona. Badacz ma być „cieniem”, z którym nie wolno rozmawiać i którego nie wolno włączać w codzienne sprawy. Wyposażony jest w arkusz obserwacji, składający się z rzutu kuchni, na którym badacz zaznacza linie poruszania się badanego oraz listy, na której prawdopodobnie zapisuje cel ruchu.

Sama obecność obcej osoby w domu człowieka, który mieszka sam, powoduje frustrację. Mężczyzna broni się przed okiem obserwatora (np. gasi światło, rozwiesza pranie, gotuje $\mathrm{w}$ sypialni), a wręcz robi mu na przekór (np. specjalnie zmienia kierunek swojego ruchu, puszcza wodę z kranu „kropla po kropli"). Badacz zaczyna wyciągać pochopne wnioski, uznając zachowanie badanego za bardzo interesujące, nie rozumiejąc kontekstu sytuacji. Badanie w paradygmacie pozytywistycznym zakłada, że jesteśmy w stanie poznać rzeczywistość taką, jaka ona jest, a badacz to "niezaangażowany naukowiec" (Guba, Lincoln 2009, s. 287). W kwestii etyki natomiast zaznacza się „nachylenie ku oszustwu” (Guba, Lincoln 2009, s. 287). Zatem nie jest istotne to, co widoczne poza wyznaczonymi ramami obserwacji, ale dokładnie to, co zostało zaobserwowane. Nie można zachowania człowieka intepretować ani próbować go rozumieć, a jedynie rejestrować. Celem takiego badania jest wyjaśnienie nomotetyczne na poziomie ogólnych prawidłowości. Eliminując kontekst, będzie można dokonać zestawienia i porównania wyników wszystkich obserwacji w domach innych badanych.

W pewnym momencie paradygmat "pęka” pod naporem naturalnych zachowań ludzkich w sytuacji spotkania. Mężczyźni zaczynają rozmawiać i wbrew założeniom badań wchodzą w interakcje. Sytuacja badawcza ulega zmianie, a badany, dzięki rozmowie i obserwacji uczestniczącej, zaczyna rozumieć zachowania badanego. Już nie tylko opisuje fakty, ale także za-

wych przeprowadził studia nad kuchnią jako miejscem pracy. Celem badań było zoptymalizowanie codziennych czynności domowych i zwiększenie ich efektywności. Po zanalizowaniu kuchennych nawyków szwedzkich gospodyń Instytut Badań Domowych uznaje, że nadszedł czas na poznanie zwyczajów kawalerów. Naukowcy mają swobodny dostęp do kuchni, będącej miejscem badań, jednak pod żadnym pozorem nie wolno im się wdawać w jakiekolwiek rozmowy z obserwowanymi mężczyznami. Głównymi bohaterami pełnej absurdalnego humoru komedii Benta Hamera są Folke, ekspert z Instytutu i Izak, żyjący na odludziu samotnik, obiekt jego badań. W miarę trwania eksperymentu ich relacje stają się coraz bardziej napięte. W końcu obaj łamią zasady przyjęte przez Instytut, co prowadzi do zaskakujących sytuacji" (http://film.wp.pl/historie-kuchenne-6027641599230593c). 
czyna je rozumieć. Po czasie okazuje się, że do podobnych „nadużyć” doszło $\mathrm{w}$ wielu obserwowanych domach i badania zostają zakończone wcześniej niż zakładano, a koordynator projektu jest przekonany o porażce.

Myślę, że film jest dodatkową lekcją podstaw metodologii, która uczy, że strategia badawcza nie działa w próżni, ale w terenie, w świecie ludzi, kultury i symboli. Ponadto żadna procedura nie zastąpi zdrowego rozsądku i kiedy pojawiają się pęknięcia, zamiast bezrefleksyjnie brnąć naprzód, warto zatrzymać się i jeszcze raz przemyśleć cel badań i jego zgodność $\mathrm{z}$ terenem badań oraz specyfiką badanego zjawiska.

\section{Bibliografia}

Babbie E. (2004), Badania społeczne w praktyce, Wydawnictwo Naukowe PWN, Warszawa.

Bauman Z. (2008), Zindywidualizowane społeczeństwo, Gdańskie Wydawnictwo Psychologiczne, Gdańsk.

Cichocki P., Jędrkiewicz T., Zydel R. (2012), Etnografia wirtualna, w: Jemielniak D. (red.), Badania jakościowe. Metody i narzędzia, Wydawnictwo Naukowe PWN, Warszawa.

Cuprjak M. (2007), Tożsamość a rola nauczyciela w okresie wczesnej dorosłości, Uniwersytet Mikołaja Kopernika, Torun.

Cuprjak M. (2010), Refleksyjny andragog a badania w działaniu, „Rocznik Andragogiczny", s. 127-140, http://www.ata.edu.pl/dokumenty/RA/RA_2010.pdf.

Cuprjak M. (2016), Konstrukcje tożsamości gimnazjalistów, Wydawnictwo Naukowe UMK, Toruń.

Czerepaniak-Walczak M. (1997), Aspekty i źródła profesjonalnej refleksji nauczyciela, Wydawnictwo EDYTOR, Torun.

Czerepaniak-Walczak M. (2010), Badanie w działaniu, w: Palka S. (red.), Podstawy metodologii badań w pedagogice, Gdańskie Wydawnictwo Psychologiczne, Sopot, s. 319-337.

Elsner D. (2000), Refleksja nad refleksyjnym praktykiem, „Nowa Szkoła”, t. 1, s. 16-20.

Frankfort-Nachmias C., Nachmias D. (2001), Metody badawcze w naukach społecznych, Wydawnictwo Zysk i S-ka, Poznań.

Guba E. G., Lincoln Y. S. (2009), Kontrowersje wokót paradygmatów, sprzeczności i wyłaniające się zbieżności, w: Denzin N. K., Lincoln Y. S. (red.), Metody badań jakościowych, t. 1, Wydawnictwo Naukowe PWN, Warszawa, s. 281-313.

Giddens A. (2010), Nowoczesność i tożsamość, Wydawnictwo Naukowe PWN, Warszawa.

Giddens A. (2009), Nowe zasady metody socjologicznej, Wydawnictwo Nomos, Kraków. 
Hejnicka-Bezwińska T. (2003), Pedagogika pozytywistyczna, w: Kwieciński Z., Śliwerski B. (red.), Pedagogika. Podręcznik akademicki, t. 1, Wydawnictwo Naukowe PWN, Warszawa, s. 196-219.

Hejnicka-Bezwińska T. (2010), Tworzenie - przekazywanie - wykorzystywanie wiedzy pedagogicznej (w perspektywie poznawczej rozwoju nauk humanistycznych), w: Piekarski J., Urbaniak-Zając D., Szmidt K. J. (red.), Metodologiczne problemy tworzenia wiedzy w pedagogice. Oblicza akademickiej praktyki, Oficyna Wydawnicza „Impuls”, Kraków, s. 41-53.

Kozinets R. (2012), Netnografia. Badania etnograficzne online, Wydawnictwo Naukowe PWN, Warszawa.

Kubinowski D. (2011), Jakościowe badania pedagogiczne. Filozofia - Metodyka - Ewaluacja, Wydawnictwo Uniwersytetu Marii Curie-Skłodowskiej, Lublin.

Kuhn T. (1968), Struktura rewolucji naukowych, Państwowe Wydawnictwo Naukowe, Warszawa.

Kwiatkowska H. (2008), Pedeutologia, Wydawnictwa Akademickie i Profesjonalne, Warszawa.

Melosik Z. (2014), Kultura popularna i tożsamość młodzieży. W niewoli władzy i wolności, Oficyna Wydawnicza „Impuls”, Kraków.

Mokrzycki E. (2007), Do nauki przychodzi się nie tylko z pytaniami, Wydawnictwo IFiS PAN, Warszawa.

Nowaczyk A. (2008), Filozofia analityczna. Z dziejów filozofii wspótczesnej, Wydawnictwo Naukowe PWN, Warszawa.

Rapior W. (2015), Intensyfikacja wyobraźni: o tożsamości osoby badacza i zawieszenia bezwarunkowej obiektywności, „Przegląd Socjologii Jakościowej”, t. 11, nr 1, s. 84-104, http://www.qualitativesociologyreview.org/PL/Volume29/ /PSJ_11_1_Rapior.pdf.

Rubacha K. (2008), Metodologia badań nad edukacją, Wydawnictwa Akademickie i Profesjonalne, Warszawa.

Rubacha K. (2010), Prawidłowości i/lub kontekst jako kryteria tworzenia wiedzy pedagogicznej, w: Piekarski J., Urbaniak-Zając D., Szmidt K. J. (red.), Metodologiczne problemy tworzenia wiedzy w pedagogice. Oblicza akademickiej praktyki, Oficyna Wydawnicza „Impuls”, Kraków, s. 55-62.

Sławecki B. (2012), Znaczenie paradygmatów w badaniach jakościowych, w: Jamielniak D. (red.), Badania jakościowe. Podejścia i teorie, Wydawnictwo Naukowe PWN, Warszawa, s. 57-87

Sztompka P. (2007), Socjologia zmian społecznych, Wydawnictwo Znak, Kraków. 